\title{
Moissanite and its bearing on the oxygen fugacity of the deeper regimes of the Earth's upper mantle
}

\author{
Woermann, E. ${ }^{1}$, Göbbels,M. ${ }^{2}$, Ulmer,G.C. ${ }^{3}$ and Grandstaff,D.E. ${ }^{3}$ \\ 1. Institut für Kristallographie, RWTH Aachen, Aachen, Germany \\ 2. Mineralogisches Institut, Universität Erlangen, Erlangen, Germany \\ 3. Geology Department, Temple University, Philadelphia, U.S.A.
}

Numerous analyses of peridotite xenoliths derived from the Earth's upper mantle by volcanic processes exhibit oxygen fugacities clustering in a narrow bracket around (FMQ \pm 1 ) for continental xenoliths and (FMQ) to (FMQ - 2) for abyssal peridotites (e.g. Wood, 1991). For samples from an ancient lithosphere even lower values in the order (FMQ - 4) were reported (e.g Kadik, 1997). All quoted oxygen fugacities are, however, too high for stable moissanite (Ulmer et al., 1998). This conspicuous discrepancy asks for an explanation.

The remarkbly persistent $\mathrm{fO}_{2}$ in continental peridotite xenoliths is indicative of a buffering process. Several models have been discussed :

- a.) The $\mathrm{Fe}^{2+} / \mathrm{Fe}^{3+}$-ratio: Both $\mathrm{Fe}^{2+}$ and $\mathrm{Fe}^{3+}$ are components of solid solution phases im the mantle. Their concentrations are thus variable. They may serve as an indicator, but nor as a buffer of $\mathrm{fO}_{2}$.

- b.) The Ni-Nio buffer pair : but $\mathrm{Ni}$ metal is typically not present in xenoliths. The buffering capacity of $\mathrm{Ni}$, due to its low concentration, is too low to exert a control over the whole mantle. The same argument holds for $\mathrm{Cu}, \mathrm{Co}$, and other elements. - c.) The CCO equilibrium : but neither $\mathrm{CO}$ nor $\mathrm{CO}_{2}$ are stable under pressure in the mantle.

- d.) Methane equilibria as

but as long as the $\mathrm{CH}_{4} / \mathrm{H}_{2} \mathrm{O}$ ratio is not defined the $\mathrm{fO}_{2}$ is variable.

- e.) Carbon-carbonate buffers, such as

$$
\mathrm{MgSiO}_{3}+\mathrm{MgCO}_{3}=\mathrm{Mg}_{2} \mathrm{SiO}_{4}+\mathrm{C}+\mathrm{O}_{2} \text { (EMOG) }
$$

(Eggler) require the universal presence of primary carbonates, which are, however, not typical in xenoliths.

Here it is proposed that by the dissociation of water :

$$
2 \mathrm{H}_{2} \mathrm{O}=2 \mathrm{H}_{2}+\mathrm{O}_{2}
$$

the desired $\mathrm{fO}_{2}$ is created. Assuming equilibrium with graphite or diamond MRK calculations show that water is the dominant fluid species in the $\mathrm{C}-\mathrm{H}-\mathrm{O}$ system under temperatures and pressures of the continental geotherm. In order to buffer the Earth's mantle an excess of water is required.

In a water free peridotite the solidus temperature increases with increasing pressure. Neither subcontinental nor suboceanic geotherms will intersect the dry peridotite solidus. An addition of water, however, drastically reduces the solidus by several hundred degrees, which may create the intersections with the geotherms, which lead to the formation of a magma. Incipient

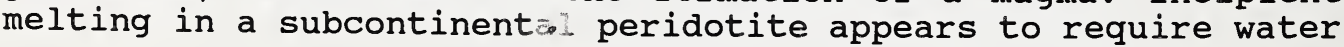


saturation. Thus it is evident that a correlation exists between the oxygen fugacity and melting.

Between the water saturated solidus $\left(a\left(\mathrm{H}_{2} \mathrm{O}\right)=1\right)$ and the dry solidus $\left(a\left(\mathrm{H}_{2} \mathrm{O}\right)=0\right)$ a solidus surface spans where the activity of water decreases with increasing temperature. With decreasing water activity, however, the oxygen fugacity decreases proportionally. This may explain why peridotites from suboceanic sources show lower oxygen fugacities and also, why ancient samples from a still hotter mantle are more reduced, or, vice versa, the observations of differing oxygen fugacities may support the model of the influence of water on $\mathrm{fO}_{2}$ discussed above.

With increasing pressures olivine reacts with water to hydrous phases according to

$$
\mathrm{Mg}_{2} \mathrm{SiO}_{4}+\mathrm{H}_{2} \mathrm{O}=\mathrm{MgSiO}_{3}+\mathrm{Mg}(\mathrm{OH})_{2}
$$

or to Dense Hydrous Magnesian Silicate Phases (DHMS), e.g. the A-phase

$$
5 \mathrm{Mg}_{2} \mathrm{SiO}_{4}+3 \mathrm{H}_{2} \mathrm{O}=3 \mathrm{MgSiO}_{3}+\mathrm{Mg}_{7}\left(\mathrm{SiO}_{4}\right)_{2}(\mathrm{OH})_{6}
$$

As long as in mantle peridotites olivine is in excess no free water will be stable under pressures above or temperatures below the corresponding monovariant reaction line, the Hydration Barrier. With $\mathrm{H}_{2} \mathrm{O}$ being absent, and also, since DHMS-phases cannot control the oxygen fugacity, the system's capacity to buffer $\mathrm{fO}_{2}$ is lost. Thus, below the hydration barrier the oxygen fugacity is undefined and may well assume values on or below the limit determined for the stability range of moissanite.

In the peridotite system the water saturated solidus and also the hydration barrier are fixed. In contrast the position of the geotherm is variable. Only a slight increase in temperature, i.e. a small addition of heat, will shift the geotherm and cause a part of the mantle to cross the hydration barrier and to liberate water, thus triggering the $\mathrm{fO}_{2}$-buffering of the surrounding and eventually the formation of a magma.

The fact that many kimberlites may contain minute amounts of moissanite thus indicates that

- these kimberlites originated from the probably deepest possible source of magma formation, the hydration barrier, and - these kimberlites contain, in the form of moissanite, relics from below the hydration barrier.

\section{References}

Wood, B.J., 1991, Oxygen barometry of spinel peridotites. In: D.H.Lindsley, Ed.: Oxide Minerals, Petrologic and Magnetic Significance, Reviews in Mineralogy 25, 415-431.

Kadik, A., 1997, Evolution of Earth's redox state during upwelling of carbon-bearing mantle. Phys. Earth Planet. Int. 100, 157-166.

Ulmer, G.C., Grandstaff,D.E., Woermann,E., Göbbels,M., Schönitz,M. and Woodland,A.B., 1998, The redox stability of moissanite, SiC, compared with metal-metal oxide buffers at $1773 \mathrm{~K}$ and at pressures up to $90 \mathrm{kbar}$. N.Jhb.Min., in press. 